\title{
Detection of Phytoplasmas in Declining Pears in Southern Australia
}

\author{
B. Schneider and K. S. Gibb, Faculty of Science, Northern Territory University, Darwin, Northern Territory, 0909, \\ Australia
}

\begin{abstract}
Schneider, B., and Gibb, K. S. 1997. Detection of phytoplasmas in declining pears in southern Australia. Plant Dis. 81:254-258.

Forty-nine pear tree samples collected in Victoria, most of them showing decline symptoms, were tested by polymerase chain reaction (PCR) analysis to detect phytoplasmas. Two universal phytoplasma-specific primer pairs, fP1/rP7 and fU5/rU3, were tested, but only fU5/rU3 amplified the phytoplasma DNA adequately. Nested PCR with universal and group-specific primers, however, proved more effective. Thirty pear trees reacted positively in a nested PCR assay. Restriction fragment length polymorphism (RFLP) analysis with the restriction enzymes MseI and $A l u \mathrm{I}$ of the PCR fragment amplified with the primer pair fU5/rU3 revealed patterns identical to those from the sweet potato little leaf phytoplasma. This is the first report of a phytoplasma in pear in Australia.
\end{abstract}

Pear is an economically important fruit crop in southern Australia. In one of the main growing areas, the Goulburn Valley in Victoria, pears with decline symptoms were recently observed. The first report of pears with decline symptoms in Australia (23) described trees in New South Wales that showed restricted foliation, interveinal chlorosis, and reduced productivity. Symptoms were often restricted to one or more limbs and were less pronounced during the summer. The same report described another disorder on pear trees designated "fissure bark." Both diseases were described separately, but no etiological agent was determined. These symptoms were similar to those found in several orchards in the Goulburn Valley.

Pear decline has been reported from most places where domestic pears are grown (30). Suppression by tetracycline treatment and transmission by grafting and vectors have provided evidence that phytoplasmas are the etiological agent of the disease $(7,21)$. Differences in symptom expression and severity of the disease have been described and referred to as quick decline, slow decline, and foliar reddening $(11,30)$.

Sequence analysis of the $16 \mathrm{~S} / 23 \mathrm{~S}$ rRNA intergenic (spacer) region showed at least four genetically different phytoplasmas associated with pear decline in California (14). The sequence of the spacer region of a phytoplasma from peach with yellow leaf roll was identical to the sequence of a

Corresponding author: B. Schneider

E-mail: bschneid@darwin.ntu.edu.au

Accepted for publication 3 October 1996.

Publication no. D-1997-0122-04R

(C) 1997 The American Phytopathological Society phytoplasma from a pear with decline (14). Genetically different phytoplasmas cause pear decline in Europe (20). Differences were not observed in the 16S rRNA gene but became apparent after amplification with nonribosomal and spacer primers.

A single type of phytoplasma may not be associated with disease in a tree. Lee et al. (17) used nested PCR to assay phytoplasmas from affected fruit trees in northern Italy and showed several different phytoplasmas from individual diseased trees and also from asymptomatic apricot, Japanese plum, pear, and Nashi pear. Nested PCR assays have proved valuable in clinical microbiology (5) and only recently were shown to improve the limit of detection and the specificity of tests for phytoplasmas $(17,18)$.

Phytoplasmas have not been confirmed on temperate fruit trees in Australia. The occurrence of pears with decline symptoms in an important commercial production area and the availability of appropriate assay techniques prompted examination of the trees for the presence of phytoplasmas.

\section{MATERIALS AND METHODS}

Plant materials. Shoot samples from 49 pear trees (Pyrus communis L. cvs. Packham and Josephine) were collected from four different orchards in the Goulburn Valley near Shepparton, Victoria. Root samples also were taken from 11 of the trees. All samples were taken between February and May 1995. Most of the trees were between 40 and 60 years old. The trees showed general dieback, poor terminal growth, and poorly developed root systems. Disease severity ranged from reduced bud viability to numerous dead limbs. Three to four shoots of about 20 to $30 \mathrm{~cm}$ were taken arbitrarily from the current season's growth on individual trees at different stages of the disease. Because feeder roots were poorly developed, the root samples were about 0.5 to $3 \mathrm{~cm}$ in diameter. Pear seedlings grown in an insect-free environment were not available, so Packham seeds were used to obtain healthy plant material. The phytoplasma strain sweet potato little leaf (SPLL) transmitted from sweet potato (Ipomoea batatas (L.) Lam.) to periwinkle (Catharanthus roseus (L.) G. Don) was used as a positive control.

Microscopic examination. Small pieces $(3 \times 3 \mathrm{~mm})$ of shoot and root tissue from all pear trees and tissue from SPLL-infected periwinkle, a positive control, were fixed in formaldehyde-glutaraldehyde (13). Thin sections cut with a cryomicrotome (Reichert, Austria) were mounted, flooded with DNA fluorochrome DAPI (4'-6'-diamidino-2-phenylindole), and visually screened for fluorescent phytoplasmas on a fluorescence microscope as previously described (28).

DNA isolation. Phloem from roots and shoots was excised, and the DNA was extracted following a phytoplasma enrichment procedure $(1,2)$. After vacuum drying, the DNA was reconstituted in $50 \mu \mathrm{l}$ of distilled water and stored at $-20^{\circ} \mathrm{C}$. DNA extracted from different parts of individual plants was kept separate. DNA from SPLL-infected periwinkle was extracted from leaf midribs using the same method. For reference, DNA from a tree known to be infected with the pear decline phytoplasma (PD) was obtained from $E$. Seemüller (Germany).

PCR conditions and primers. PCR was performed in a thermal cycler (PerkinElmer Cetus model 480, Melbourne, Victoria, Australia) in a volume of $50 \mu \mathrm{l}$ containing 50 to $100 \mathrm{ng}$ of DNA, $0.25 \mu \mathrm{M}$ of each primer, $100 \mu \mathrm{M}$ of each nucleotide, $0.2 \mathrm{U}$ Red Hot DNA polymerase, and 1× polymerase buffer (Advanced Biotechnologies Ltd., Surrey, UK). The mixture was overlaid with $30 \mu \mathrm{l}$ of mineral oil and subjected to 35 or 70 cycles consisting of 1 min denaturation at $95^{\circ} \mathrm{C}, 1 \mathrm{~min}$ annealing at $55^{\circ} \mathrm{C}$, and $1.5 \mathrm{~min}$ extension at $72^{\circ} \mathrm{C}$. The initial PCR was performed with the universal primer pairs $\operatorname{fP} 1 / \mathrm{rP} 7(8,15)$ and fU5/rU3 (20). After 35 cycles, $15 \mu \mathrm{l}$ of each reaction mixture was removed and 1 $\mu \mathrm{l}$ from the fP1/rP7 assay was amplified by the universal primer pair fU5/rU3, the sunn-hemp group-specific primer pair fU5/rSPLLS, or the European fruit treespecific primer pair fO1/rO1 (20). Nested primers are hereafter indicated by an " $n$ " preceding the primer designation. The 
reaction product from the positive control SPLL was diluted 1:1,000 before nested PCR. All pipetting for nested PCR assays was done with a positive displacement pipette to avoid a carryover of PCR products. To determine if pear DNA had PCR inhibitors, DNA from SPLL-infected periwinkle was assayed in a mixture with pear DNA.

Primer selection. Primer rSPLLS (5'AGATGATTGATTTTATTGG-3') was selected after spacer region sequences of phytoplasmas representing the major taxonomic groups $(15,27,31)$ were aligned using the computer program Pileup (GCG, University of Wisconsin). Primer rSPLLS is specific for phytoplasmas belonging to the sunn-hemp group (comprising sunnhemp phyllody [SUNHP], faba bean phyllody [FBP], tomato big bud [TBB], and SPLL phytoplasmas) (15). For the oligonucleotide hybridization, the primers rU3, 16R723f (22), and rSPLLS were used. Primers rU3 and 16R723f are derived from conserved regions of the $16 \mathrm{~S}$ rRNA gene of the Oenothera aster yellows phytoplasma (19).

Analysis of PCR products. The products $(5 \mu \mathrm{l})$ of each PCR reaction were electrophoresed on a $1 \%$ agarose gel containing ethidium bromide at $0.3 \mu \mathrm{g} \mathrm{ml}^{-1}$ in $0.5 \times$ TBE buffer $(1 \times$ is $45 \mathrm{mM}$ Tris-borate and $1 \mathrm{mM}$ EDTA, pH 8.0). The DNA was visualized and photographed while exposed to UV (302 nm) light. For restriction fragment length polymorphism (RFLP) analysis, 5 to $10 \mu \mathrm{l}$ of each reaction product was incubated with $5 \mathrm{U}$ of MseI or AluI (New England Biolabs, Beverly, MA) following the manufacturer's protocols. RFLP patterns were determined on $8 \%$ polyacrylamide gel in $1 \times \mathrm{TBE}$. The gel was stained with ethidium bromide at 0.5 $\mu \mathrm{g} \mathrm{ml}^{-1}$ and visualized and photographed as described. Fragment sizes were estimated using the 1-kb ladder (BRL-Life Technologies, Melbourne).

Southern blotting and oligonucleotide hybridization. Agarose gels were blotted to nylon membranes (Hybond N, Amersham, Sydney, NSW, Australia), and the DNA was fixed by baking the membrane at $80^{\circ} \mathrm{C}$ for $2 \mathrm{~h}$ (26). The membranes were prehybridized at $40^{\circ} \mathrm{C}$ for $2 \mathrm{~h}$ in a solution containing $6 \times$ SSPE $(1 \times$ is $150 \mathrm{mM} \mathrm{NaCl}$, $10 \mathrm{mM} \mathrm{Na} \mathrm{HPO}_{4}$, and $1 \mathrm{mM}$ EDTA, $\mathrm{pH}$ 7.6), $5 \times$ Denhardt's solution $(1 \times$ is $0.02 \%$ Ficoll, $0.02 \%$ polyvinylpyrrolidone [PVP], and $0.02 \%$ bovine serum albumin [BSA]), $0.5 \%$ sodium dodecyl sulfate (SDS), $0.05 \% \mathrm{Na}_{4} \mathrm{P}_{2} \mathrm{O}_{7}$ (PPi), and denatured herring sperm DNA at $100 \mu \mathrm{g} \mathrm{ml}^{-1}$. Hybridization was performed at $40^{\circ} \mathrm{C}$ overnight in the same solution containing $20 \mathrm{ng}$ of either oligonucleotide 16R723f, rU3, or rSPLLS. The oligonucleotides were endlabeled with $\left[\gamma^{32} \mathrm{P}\right]$ ATP using $5 \mathrm{U}$ of T4 polynucleotide kinase following the manufacturer's protocol (Promega, Rozelle, NSW). After hybridization, the membrane was washed twice for $15 \mathrm{~min}$ in $6 \times$ SSPE,
$0.05 \% \mathrm{PPi}$, and twice for $15 \mathrm{~min}$ in $2 \times$ SSPE, $0.05 \% \mathrm{PPi}$, both at $40^{\circ} \mathrm{C}$. The membranes were exposed to $\mathrm{X}$-ray film (Hyperfilm-MP, Amersham) at $-80^{\circ} \mathrm{C}$ in cassettes containing intensifier screens. Labeled oligonucleotide was removed by boiling the membranes in $0.5 \%$ SDS.

\section{RESULTS}

Microscopic examination. DNA fluorescence typical for sieve tubes containing phytoplasmas was not observed in any of the 49 pear trees, indicating either absence or a low titer of phytoplasmas. However, a fluorescence typical for phytoplasmas was clearly visible in the sieve tubes of SPLLinfected periwinkle.

Amplification with fP1/rP7 and fU5/rU3. After 35 cycles, the universal primer pair $\mathrm{fP} 1 / \mathrm{rP} 7$ amplified the DNA of only the SPLL and the known PD phytoplasma to a DNA band visible on a gel. The amplification product was the expected size of about $1,750 \mathrm{bp}$. No amplification product was visible after processing DNA from pear samples. After 70 cycles, a strong DNA smear was present in lanes for all samples, including the positive controls, indicating an unspecific amplification of DNA. The universal primer pair fU5/rU3 amplified DNA from the samples adequately to allow band distinction. After 35 cycles, bands were visible in the lanes corresponding to controls SPLL and PD, and faint bands were present in 15 of 25 pear samples tested. Figure 1 shows the band from one pear sample. The yield of product was increased by doubling the

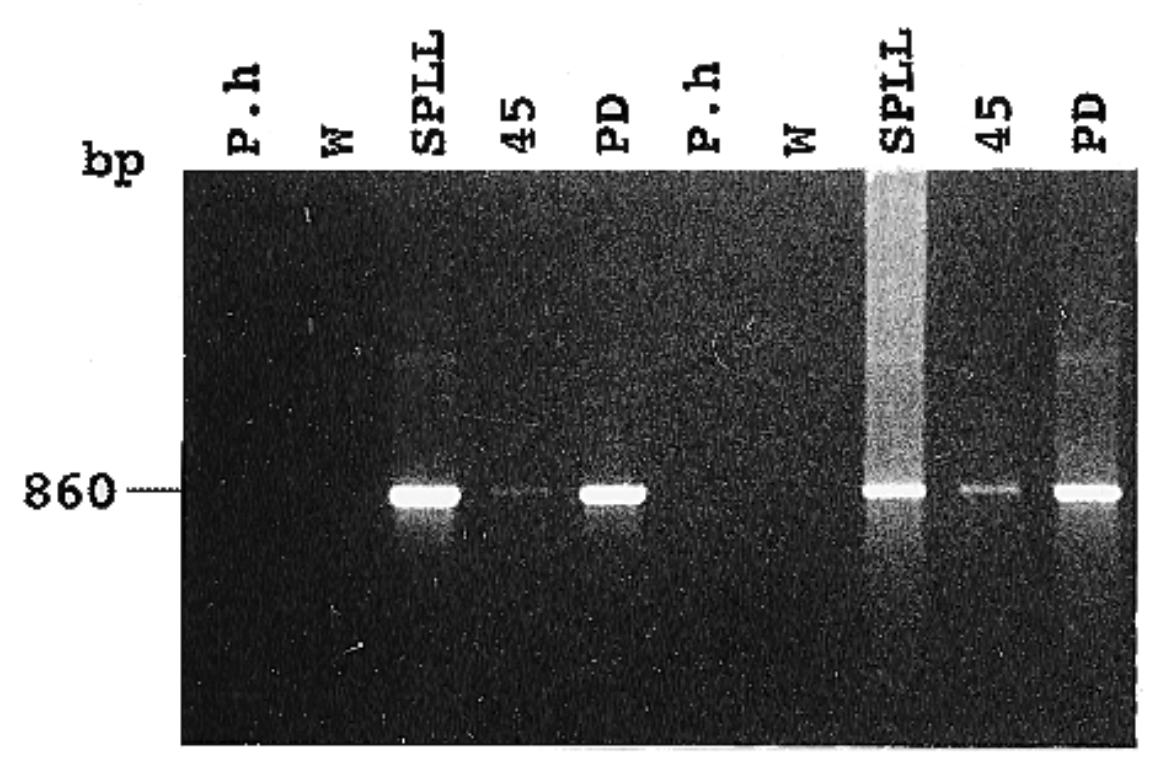

Fig. 1. Polymerase chain reaction (PCR) amplified 16S rRNA fragments obtained with the primer pair fU5/rU3. The samples were subjected to either 35 (five lanes on the left) or 70 (five lanes on the right) PCR cycles. P.h = healthy pear; $\mathrm{W}=$ water control; SPLL = sweet potato little leaf phytoplasma; 45 = field-collected pear sample PD = pear decline phytoplasma. The DNA marker is not shown, but the size of the fragment or the size corresponding to marker fragments is indicated in base pairs.

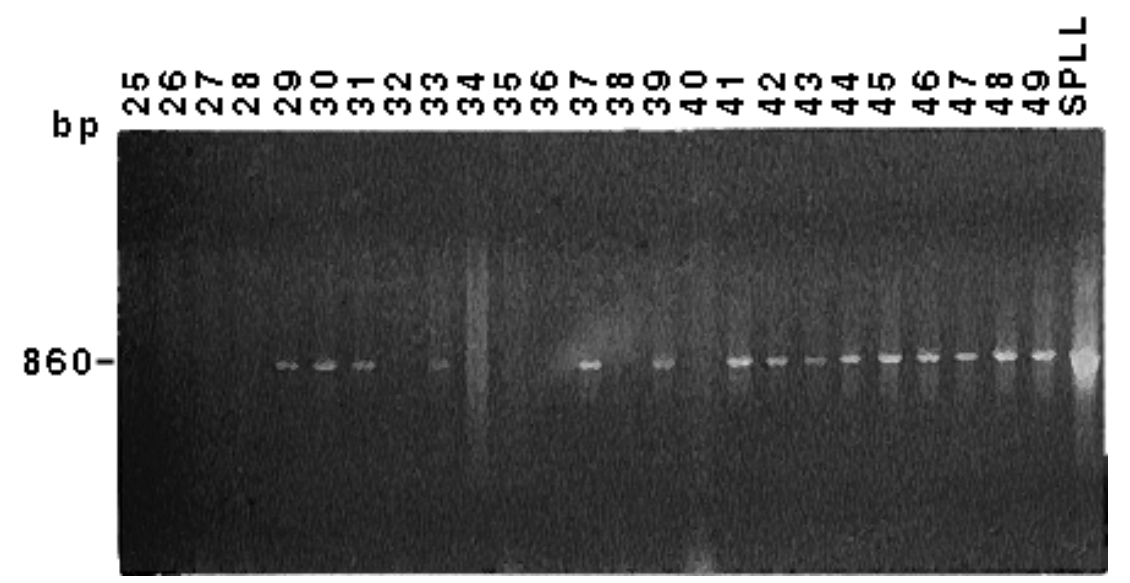

Fig. 2. Polymerase chain reaction (PCR) amplified 16S rRNA fragment obtained with the primer pair fU5/rU3. The samples were subjected to 70 PCR cycles. The numbers 25 to 49 refer to the pear sample number. SPLL = sweet potato little leaf phytoplasma. The DNA marker is not shown, but the size of the fragment or the size corresponding to marker fragments is indicated in base pairs. 
number of cycles to 70. However, a faint DNA smear was visible in reactions processed for 70 cycles. All bands had the expected size of about 860 bp (Fig. 2). After 70 cycles, DNA from the healthy control was not amplified by any primer combination. When DNA of SPLL-infected periwinkle was amplified in the presence of pear DNA, amplification proceeded and amplification products were detected, indicating that no PCR inhibitors were present.

Oligonucleotide hybridizations. When the products of DNA amplification with primer pair $\mathrm{fP} 1 / \mathrm{rP} 7$ for 35 cycles were blotted and hybridized with either rU3 or 16R723f, 12 of 49 pear samples hybridized with each oligonucleotide. In both hybridizations, the same samples hybridized to the oligonucleotides (data not shown). Twenty- five $\mathrm{fP} 1 / \mathrm{rP} 7 \mathrm{PCR}$ products (sample 25 to 49) were hybridized with oligonucleotide rSPLLS, and six samples hybridized at a position corresponding in size to the fP1/rP7 product. Representative results from samples 40 to 49 are shown in Figure 3 . Five other samples showed a hybridization signal at a different position. The $\mathrm{fP} 1 / \mathrm{rP} 7$ product of SPLL gave a strong reaction with the homologous oligonucleotide. After 35 and 70 cycles, the fU5/rU3 amplification products of samples 25 to 49 were blotted and hybridized with the oligonucleotide 16R723f; 15 and 17 pear samples, respectively, hybridized with the oligonucleotide (Fig. 4, some data not shown). The hybridization signal of sample 34 was visible after 35 cycles but was covered by a DNA smear after 70 cycles. An

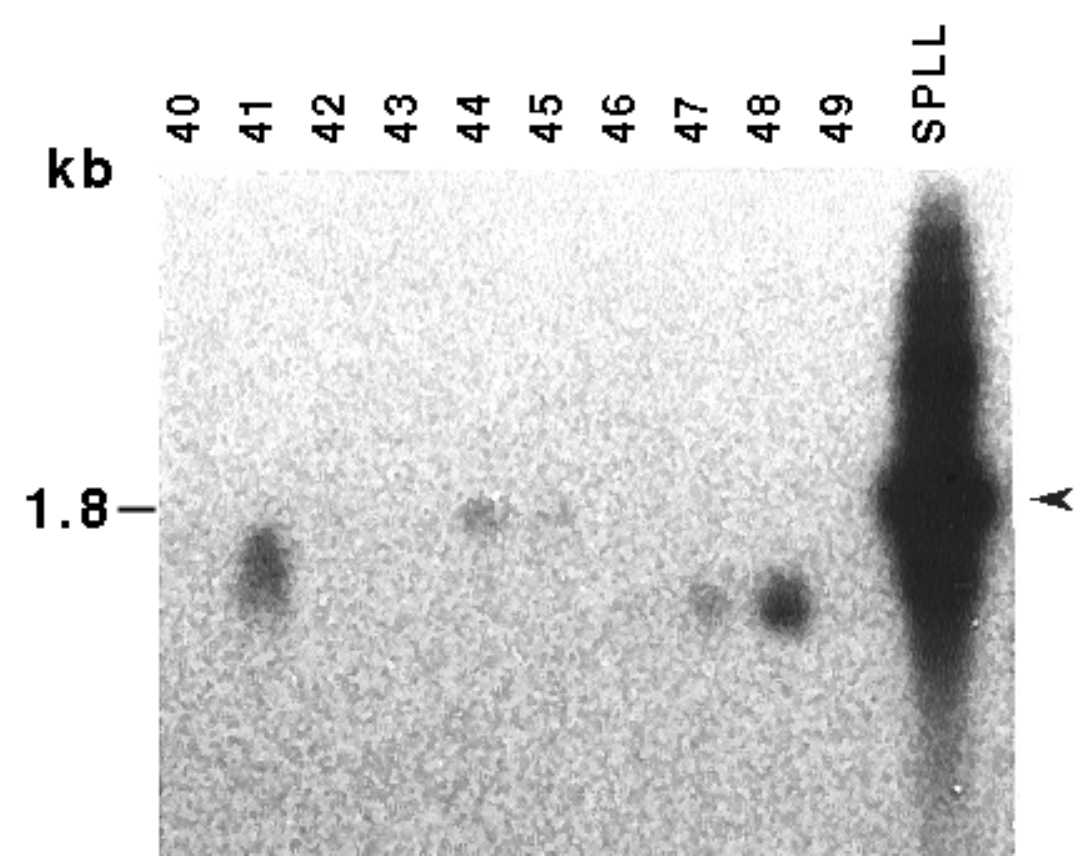

Fig. 3. Southern-blot hybridization with oligonucleotide rSPLLS. The Southern-blotted polymerase chain reaction (PCR) fragments were amplified with the primer pair $\mathrm{PP} 1 / \mathrm{rP} 7$ for 35 cycles. The arrow indicates the hybridization equivalent in size to the $\mathrm{fP} 1 / \mathrm{rP} 7$ fragment of the sweet potato little leaf (SPLL) phytoplasma. The numbers on top refer to the pear sample number. The DNA marker is not shown, but the size of the fragment or the size corresponding to marker fragments is indicated in kilobase pairs.

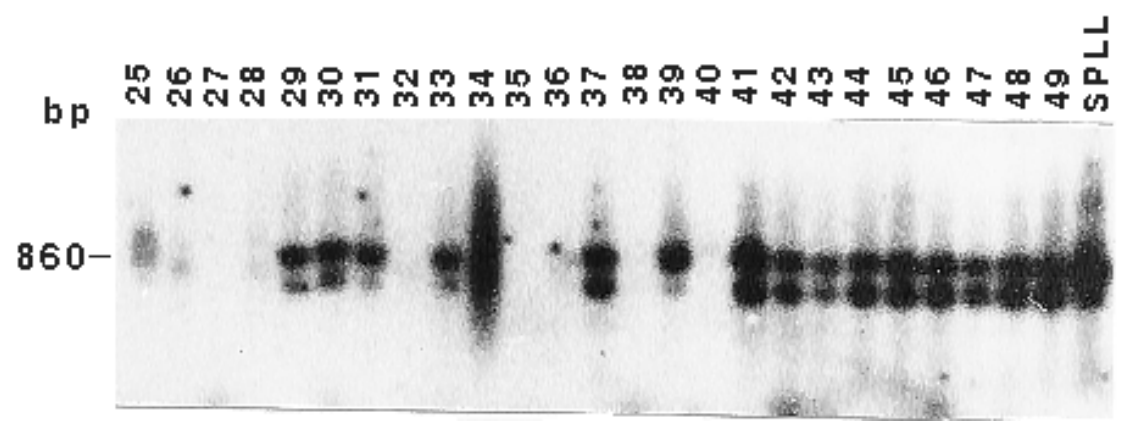

Fig. 4. Southern-blot hybridization with oligonucleotide 16R723f. The Southern-blotted polymerase chain reaction (PCR) fragments were amplified with the primer pair fU5/rU3 for 70 cycles. SPLL = sweet potato little leaf phytoplasma. The DNA marker is not shown, but the size of the fragment or the size corresponding to marker fragments is indicated in base pairs.

additional band of about 800 bp (lower hybridization signal in Figure 4) hybridized with 16R723f after 70 cycles, but it was not visible after gel electrophoresis; this hybridization was removed by more stringent posthybridization washes (data after washing not shown).

Nested PCR. To increase detection, a nested PCR was performed using the primer pairs nfU5/rU3, nfU5/rSPLLS, and nfO1/rO1. Products of amplification were visible with 28 of 49 samples with nfU5/rU3 (data not shown). Products of amplification with nfU5/rSPLLS were visible for 20 of 25 samples (Fig. 5). When the same samples were compared with both primers, nfU5/rSPLLS amplified DNA from an additional two samples. With the primer pair nfO1/rO1, no amplification product was visible except for PD (data not shown). No amplification product was visible when any nested primer pairs were cycled with the healthy pear seed control.

RFLP pattern. Products from fU5/rU3 amplification were digested with restriction enzymes $M s e \mathrm{I}$ and $A l u \mathrm{I}$. The RFLP pattern obtained from both digests was identical to that of the SPLL phytoplasma (Fig. 6). No differences in RFLP patterns were found among the phytoplasmas.

\section{DISCUSSION}

Pear decline is an economically important disease reported from most countries where pears are grown (30). This is the first report of a phytoplasma associated with pear decline in Australia. The most obvious symptom associated with the disease is a loss of vigor that progresses to dieback of limbs. Routine assays on clinical specimens failed to associate declining pears with pathogenic fungi or nematodes, although investigations were not exhaustive (D. Eagling, personal communication).

Fluorescence microscopy is a simple technique to detect phytoplasmas in pears with decline symptoms (29). In our tests, fluorescence microscopy was not sufficiently sensitive to detect the organisms, perhaps because populations were low. Phytoplasmas could only be detected by PCR assays, the most sensitive detection method for phytoplasmas at present. With this technique, 30 of 49 tested trees were shown to be infected with phytoplasmas. Although most of the sampled trees showed decline symptoms, there was no clear association between symptom severity and demonstrated presence of phytoplasmas. Phytoplasmas were not found in 19 samples from apparently infected trees. Both symptoms and phytoplasmas were found in trees of Packham and Josephine. Susceptibility of cultivars has to be studied in more detail.

We tried to detect the phytoplasmas with the universal phytoplasma primer pairs $\mathrm{fP} 1 / \mathrm{rP} 7$ and fU5/rU3, combinations that successfully detected other phytoplasmas $(10,22)$; however, fP1/rP7 failed to amplify 
the pear phytoplasma DNA sufficiently for visual detection. Oligonucleotide hybridization to Southern-blotted PCR products indicated that the target molecule was amplified. Poor amplification might be explained by the nature of the primers but cannot be attributed to inhibitors because DNA from a positive control amplified in the presence of host DNA. The presence of hybridization signals at a different site could reflect incompletely amplified PCR products; however, this possibility must be investigated further. The increase in the number of positive samples after hybridization and nested PCR clearly reflects the higher amplification potential of both assays $(3,16)$. The primer pair fU5/rU3 amplified the DNA of the pear phytoplasma to a detectable amount, but the yield of PCR product was low after 35 cycles. We tried to enhance the amplification by increasing the number of PCR cycles. This modification was successful for detection of phytoplasmas from lethal yellowing diseased coconut palms (25). The primer pairs $\mathrm{fP} 1 / \mathrm{rP} 7$ and fU5/rU3 reacted differently when cycle numbers were increased to 70; $\mathrm{fP} 1 / \mathrm{rP} 7$ amplified DNA nonspecifically, and fU5/rU3 increased the yield of the target amplification product. Primer pair fU5/rU3 did amplify DNA nonspecifically, but to a lesser extent. Overamplification might explain the apparent loss of product from SPLL and PD after 70 cycles (Fig. 1). High cycle numbers have been known to reduce yield and even cause total disappearance of the target PCR product (6). However, we think that overamplification is not responsible for the low yield of PCR product from the pear samples. More likely, reduced polymerase activity or availability of PCR components restricted yield.

PCR reactions are sensitive to contamination, and foreign DNA can be amplified, especially when high numbers of cycles are performed. This was the rationale for hybridizing the fU5/rU3 product with the internal oligonucleotide 16R723f to establish the purity of the amplification product. $16 \mathrm{R} 723 \mathrm{f}$ is fully homologous to the corresponding region of the $16 \mathrm{~S}$ rRNA gene of phytoplasmas and acholeplasmas, but it has two or more mismatches with other prokaryotes. Oligonucleotide hybridizations are highly specific, and target sequences with only one mismatch can be distinguished under appropriate conditions (12). The result obtained from the oligonucleotide hybridization agrees with the result from the nested PCR assays, with the exception of sample 25, which showed a hybridization signal but was negative after nested PCR. However, the distribution of phytoplasmas in plants is probably not uniform, and the DNA extracted from sample 25 for one test may have been from an infected branch, whereas tissues for other tests may have come from branches without phytoplasmas.
Nested PCR with nfU5/rU3 and nfU5/rSPLLS was the technique with the lowest detection limit. However, nested PCR is highly susceptible to contamination because PCR products have to be manipulated (24). We tried to avoid contamination by physically separating the pipetting steps and by using a positive displacement pipette. No other technique is as sensitive as nested PCR at the moment; hence it is difficult to confirm our results by other methods. When we tried to confirm nested PCR results independently by oligonucleotide hybridization of the $\mathrm{PP} 1 / \mathrm{rP} 7$ product or by increasing the cycle number in PCR, we were unable to obtain the same number of positive samples.

To characterize the phytoplasma from pear, we performed an RFLP analysis of the fU5/rU3 product of the pear samples and the SPLL phytoplasma. The resulting patterns were identical. The SPLL phytoplasma is closely related to phytoplasmas associated with papaya yellow crinkle and papaya mosaic (9). A recent survey indicated that phytoplasmas of that group are prevalent in Australia and occur in a wide range of different host plants $(4,9 ; \mathrm{R}$. Davis, personal communication). The possibility that phytoplasmas belonging to the SPLL-group are the causal agent of pear decline is in agreement with recent data from the United States and Europe, where pear decline is associated with genetically different phytoplasmas $(14,20)$. This could explain the differences in symptomatology, which is not identical to published descriptions $(11,30)$. The fact that the majority of declining pears are 40 to 60 years old requires further investigation. Rootstocks and cultivars with a moderate to high resistance to pear decline are known (30), but the origin of the rootstocks of the 40to 60-year-old trees is mostly unknown. Little is known regarding tree age and susceptibility, and infection of old trees may be coincidental. Similarly, little is known about potential sources of inoculum. In determining the role of phytoplasmas in pear decline in Australia, molecular techniques combined with traditional techniques may provide answers more rapidly.

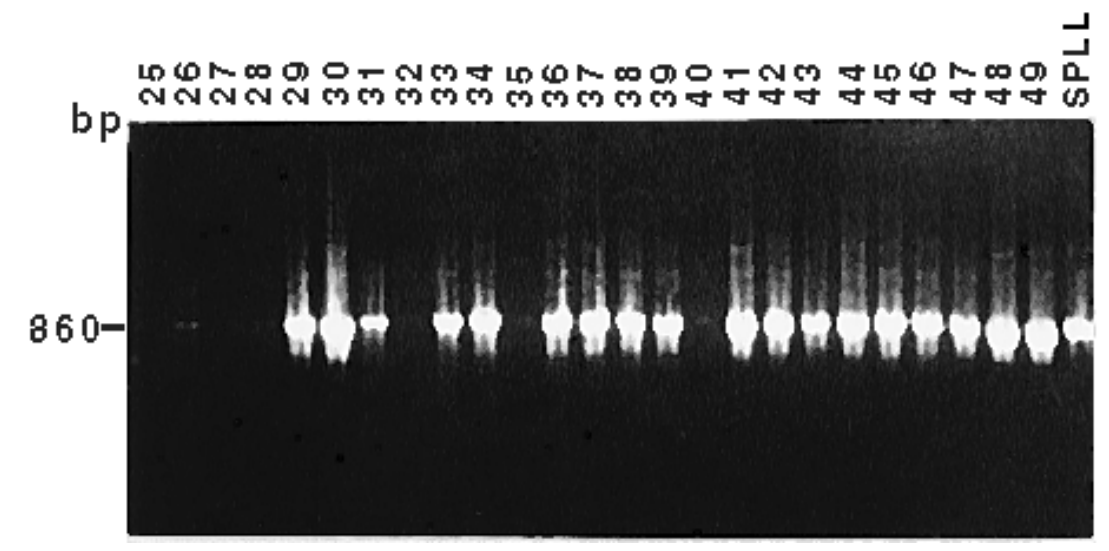

Fig. 5. Nested polymerase chain reaction (PCR) amplification of the 16S rRNA gene and part of the spacer region with the primer pair nfU5/rSPLLS. SPLL = sweet potato little leaf phytoplasma. The DNA marker is not shown, but the size of the fragment or the size corresponding to marker fragments is indicated in base pairs.

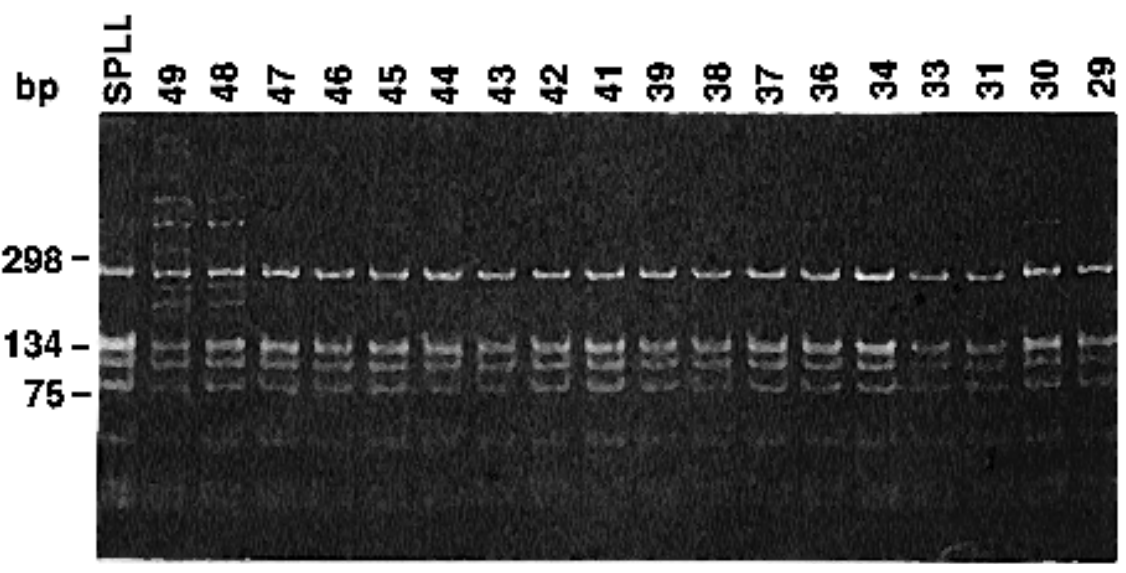

Fig. 6. Polyacrylamide gel electrophoresis of the MseI-digested fU5/rU3 amplification product. The numbers on top of the gel refer to the pear sample number. SPLL = sweet potato little leaf phytoplasma. The DNA marker is not shown, but the size of the fragment or the size corresponding to marker fragments is indicated in base pairs. 


\section{ACKNOWLEDGMENTS}

We thank D. Eagling (Institute for Horticultural Development, Knoxfield, Victoria) and P. Jobling (Northern Victoria Fruit Growers Association, Shepparton, Victoria) for collecting plant material. We thank the Australian Centre for International Agricultural Research, the Northern Territory University, and the Northern Victoria Fruit Growers Association for providing financial assistance.

\section{LITERATURE CITED}

1. Ahrens, U., and Seemüller, E. 1992. Detection of DNA of plant pathogenic mycoplasmalike organisms by a polymerase chain reaction that amplifies a sequence of the $16 \mathrm{~S}$ rRNA gene. Phytopathology 82:828-832.

2. Ahrens, U., and Seemüller, E. 1994. Detection of mycoplasmalike organisms in declining oaks by polymerase chain reaction. Eur. J. For. Pathol. 24:55-63.

3. Altwegg, M. 1995. General problems associated with diagnostic applications of amplification methods. J. Microbiol. Meth. 23:21-30.

4. Bowyer, J. W. 1974. Tomato big bud, legume little leaf, and lucerne witches' broom: Three diseases associated with different mycoplasma-like organisms. Aust. J. Agric. Res. 25:449-457.

5. Catalan, V., Moreno, C., Dasi, M. A., Munoz, C., and Apraiz, D. 1994. Nested polymerase chain reaction for detection of Legionella pneumophila in water. Res. Microbiol. 145:603-610.

6. Cha, R. S., and Thilly, W. G. 1993. Specificity, efficiency, and fidelity of PCR. PCR Meth. Appl. 3:S18-S28.

7. Davis, D. L., Guise, C. M., Clark, M. F., and Adams, A. N. 1992. Parry's disease of pear is similar to pear decline and is associated with mycoplasma-like organisms transmitted by Cacopsylla pyricola. Plant Pathol. 41:195203.

8. Deng, S., and Hiruki, C. 1991. Amplification of $16 \mathrm{~S}$ rRNA genes from culturable and nonculturable Mollicutes. J. Microbiol. Meth. 14:53-61.

9. Gibb, K. S., Padovan, A. C., and Mogen, B. D. 1995. Studies on sweet potato little-leaf phytoplasma detected in sweet potato and other plant species growing in northern Australia. Phytopathology 85:169-174.

10. Gibb, K. S., Persley, D. M., Schneider, B., and Thomas, J. E. 1996. Phytoplasmas associated with papaya diseases in Australia. Plant Dis. 80:174-178.

11. Guinchedi, L., Pollini, C. P., Biondi, S., and Babini, A. R. 1994. PCR detection of MLOs in quick decline-affected pear trees. Ann. Appl. Biol. 124:399-403.

12. Jenkins, F. J. 1994. Basic methods for the detection of PCR products. PCR Meth. Appl. 5:S77-S82.

13. Karnovsky, M. J. 1965. A formaldehydeglutaraldehyde fixative of high osmolality for use in electron microscopy. J. Cell. Biol. 27:137-138.

14. Kirkpatrick, B. C., Purcell, A. H., Gao, J. L., Fisher, G. F., and Uyemoto, J. K. 1993. At least three genetically distinct MLOs cause pear decline and peach yellow leafroll disease in California. Phytopathology 83:1341.

15. Kirkpatrick, B. C., Smart, C., Gardner, S., Gao, J.-L., Ahrens, U., Mäurer, R., Schneider, B., Lorenz, K.-H., Seemüller, E., Harrison, N., Namba, S., and Daire, X. 1994. Phylogenetic relationship of plant pathogenic MLOs established by $16 / 23 \mathrm{~S}$ rDNA spacer sequence. IOM Lett. 3:228-229.

16. Lazar, J. G. 1994. Advanced methods in PCR product detection. PCR Meth. Appl. 4:S1-S14.

17. Lee, I.-M., Bertaccini, A., Vibio, M., and Gundersen, D. E. 1995. Detection of multiple phytoplasmas in perennial fruit trees with decline symptoms in Italy. Phytopathology 85:728-735.

18. Lee, I.-M., Gundersen, D. E., Hammond, R. W., and Davis, R. E. 1994. Use of mycoplasmalike organism (MLO) group-specific oligonucleotide primers for nested-PCR assays to detect mixed-MLO infections in a single host plant. Phytopathology 84:559-566.

19. Lim, P.-O., and Sears, B. B. 1989. 16S rRNA sequence indicate that plant-pathogenic mycoplasmalike organism are evolutionary distinct from animal mycoplasmas. J. Bacteriol. 171:5901-5906.

20. Lorenz, K.-H., Schneider, B., Ahrens, U., and Seemüller, E. 1995. Detection of the apple proliferation and pear decline phytoplasmas by PCR amplification of ribosomal and nonribosomal DNA. Phytopathology 85:771-776.

1. Nyland, G., and Moller, W. J. 1973. Control of pear decline with a tetracycline. Plant Dis. Rep. 57:634-637.
22. Padovan, A. C., Gibb, K. S., Bertaccini, A Vibio, M., Bonfiglioli, R. E., Magarey, P. A. and Sears, B. B. 1995. Molecular detection of the Australian grapevine yellows phytoplasma and comparison with grapevine yellows from Italy. Aust. J. Grape Wine Res. 1:25-31.

23. Pares, R. D., and Hutton, K. E. 1961. Virus diseases of pome fruit in New South Wales. Agric. Gaz. N.S.W. 72:414-421.

24. Razin, S. 1994. DNA probes and PCR in diagnosis of mycoplasma infections. Mol. Cell. Probes 8:497-511.

25. Rohde, W., Kullaya, A., Mpunami, A., and Becker, D. 1993. Rapid and sensitive diagnosis of mycoplasmalike organisms associated with lethal disease of coconut palm by a specifically primed polymerase chain reaction for the amplification of $16 \mathrm{~S}$ rDNA. Oléagineux 48:319-322.

26. Sambrook, J., Fritsch, E., and Maniatis, T. 1989. Molecular Cloning: A Laboratory Manual. 2nd ed. Cold Spring Harbor Laboratory, Cold Spring Harbor, NY.

27. Schneider, B., Seemüller, E., Smart, C. D. and Kirkpatrick, B. C. 1995. Phylogenetic classification of plant pathogenic mycoplasma-like organisms or phytoplasmas. Pages 369-380 in: Molecular and Diagnostic Procedures in Mycoplasmology. Vol. I, Molecular Characterization. R. Razin and J. G. Tully, eds. Academic Press, San Diego, CA.

28. Seemüller, E. 1976. Investigations to demonstrate mycoplasmalike organisms in diseased plants by fluorescence microscopy. Acta Hortic. 67:109-111.

29. Seemüller, E. 1976. Demonstration of mycoplasma-like organisms in the phloem of trees with pear decline or proliferation symptoms by fluorescence microscopy. J. Phytopathol. 85:368-372.

30. Seemüller, E. 1992. Pear decline. Pages 308334 in: Plant Diseases of Economical Importance, Vol. III. J. Kumar, H. S. Chaube, U. S. Singh, and Mukhopadhyay, eds. Prentice Hall, Englewood Cliffs, NJ.

31. Seemüller, E., Schneider, B., Mäurer, R., Ahrens, U., Daire, X., Kison, H., Lorenz, K. H., Firrao, G., Avinent, L., Sears, B. B., and Stackebrandt, E. 1994. Phylogenetic classification of phytopathogenic mollicutes by sequence analysis of $16 \mathrm{~S}$ ribosomal DNA. Int J. Sys. Bacteriol. 44:440-446. 